\section{Liliya Ametova Кімія Аметова}

Computer Graphics Lecturer, Kyiv Engineering High School, postgraduate student of Borys Grinchenko Kyiv University викладач комп'ютерної графіки Київської інженерної гімназії,

аспірантка Київського університету імені Бориса Грінченка

e-mail: lilya-ametova@ukr.net orcid.org/0000-0001-8785-8701

\title{
Glamorous Ukrainian Motifs in the Murals by Eugenia Gapchinska
}

\author{
ГАамурна україніка \\ в мурамах Євгенії Гапчинської
}

\begin{abstract}
Certain motifs in the artworks of E. Gapchinska, a Ukrainian painter of the early $21^{\text {st }}$ century, were analyzed, which have been implemented in the contemporary mural art. The scope of the key topics and storylines attributable to the Ukrainian authenticity in her creative artworks has been determined. Such paintings, as The Sky in My Palms (2006), A Piece of Bread with Lard (2008) (the mural replica at 102 Kalynova Street, Dnipro City, 2019), Viryovka Folk Choir (2009) (?), Nina Matviyenko (2010), A Ring Means Your Love... (2011), I Can Do Wonders (2013), I'm Yours (2010 (?)), and some angel motifs, inspiring the V. Gidevan's mural painting project in Chernihiv City (2017), were studied. The author has ascertained the specific features of the painter's creative method in her field. Keywords: glamour, mural art, Eugenia Gapchinska, Ukrainian authenticity, Chernihiv City, Dnipro City.
\end{abstract}

Problem statement. Among contemporary Ukrainian artists, E. Gapchinska stands out due to certain universality of her artworks. The painter, who is predominantly known as an easel painter and a book graphics painter, recently has shown interest not only in miniatures, like jewelry, porcelain cups or puzzles, but also in huge monumental mural paintings $[5 ; 10]$.

The artist's specific feature in mural art and easel artworks is her authentic creative manner, since E. Gapchinska is working in the stream of modern glamour, extending her own artistic horizons. Therefore, she may, sometimes, take the plunge of being the "queen of candy wrappers" finding no understanding on the part of professional artists, and, sometimes, she may embark on creative projects on the verge of roguish street art. Consequently, E. Gapchinska's pilot mural designs stir interest in terms of the topic and storyline choice, and consumer response. As a matter of fact, the motifs of chamber and sentimental easel artworks bordering, stylistically, on book illustrations are transposed into design environments.

Analysis of recent research works and publications. In terms of a "tempting image", glamour is given consideration in works of the American scientist, a modern media development expert at Warwick University, Professor S. Gundle, who has served on academic posts in Oxford, Cambridge, London, Norfolk, and then in New York for many years. Viewing glamour as a part of a modern fashionable and popular lifestyle connected with the Hollywood values, the author in his book Glamour tried to explain this phenomenon as a part of the contemporary pop-culture, business market, fashion industry, politics; style, fakes and excess; eroticism and publicity [9].

A Philosophy to Street Art and the Law [8], a work by A. Baldini, an Italian scientist, Professor of Aesthetics and Art Theory at School of Arts of Nanjing University, China, is devoted to understanding of the phenomenon of consumption of artistic demonstrative visions in the social reality, in particular, in mural paintings. In this work, contemporary street art is construed as a part of counter visions (counter imager) which, in one way or other, makes impression on surrounding people, irrespective of their will. Street art quite aggressively enters personal space through unappelable agitation based on promotion of the primary elements of poster art and advertising.

At the same time, E. Gapchinska's embarking on mural art has not been separately considered in works of Ukrainian art experts. Instead, general features of her artworks related to extrapolation of imagery in easel works into applied and decorative arts and design fields have been researched by O. Shkolna, Doctor in Art Theory, who in her article "Integrating of Painting Artworks in Environment Designs Through the Example of Eugenia Gapchinska's Artworks" published in Artprostir periodical [6], made the first attempt of scientific substantiation of the artist's artworks in different applied areas. 


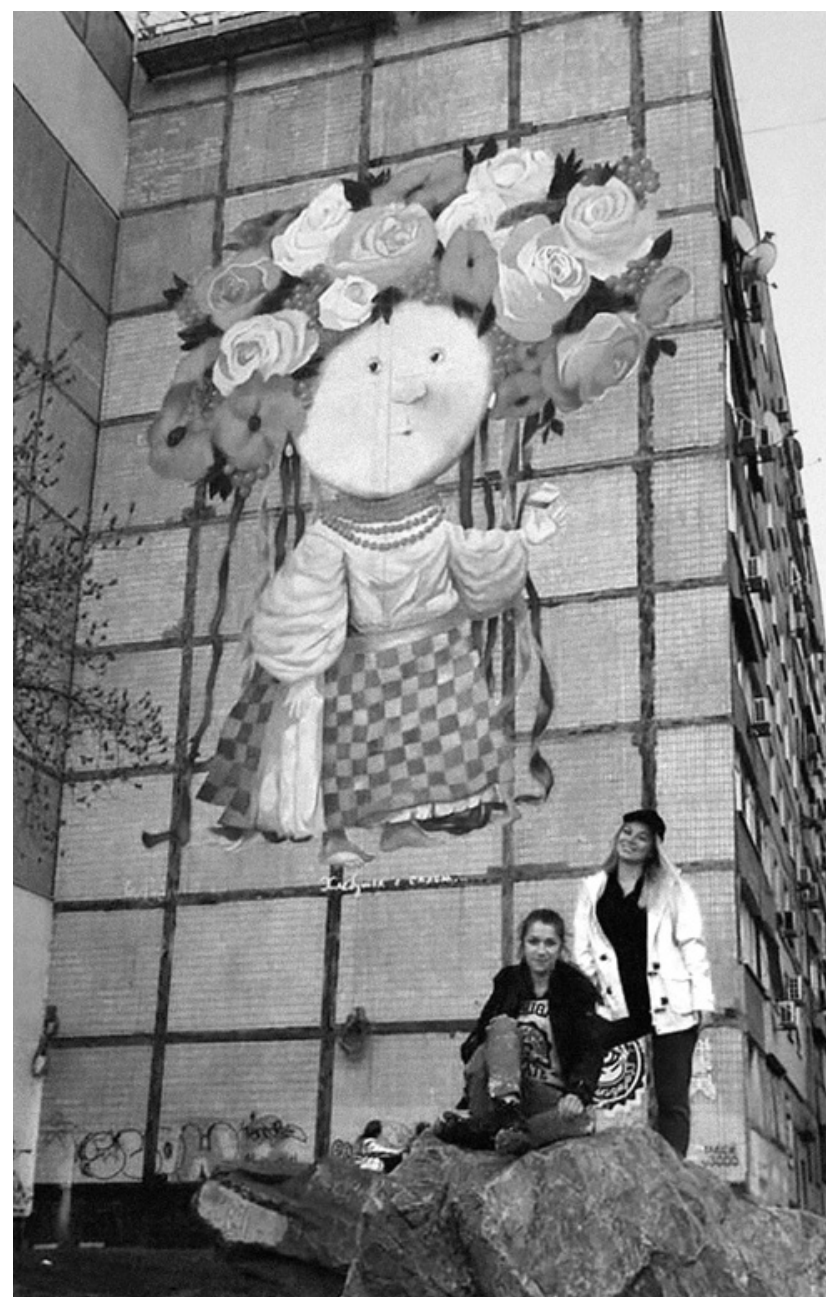

The first mural painting based on the motif of the E. Gapchinska's little angels with a cat implemented by V. Gidevan in 2017 became known due to several articles in Ukrainian periodicals. For instance, one of such articles says that the street painter chose the popular motive from Gapchinska's artworks to make a mural painting in Chernihiv City. The choice of such a soft motif generally finds no contradiction to the image of the good by any age and gender category of the local community or contradiction to the artistic

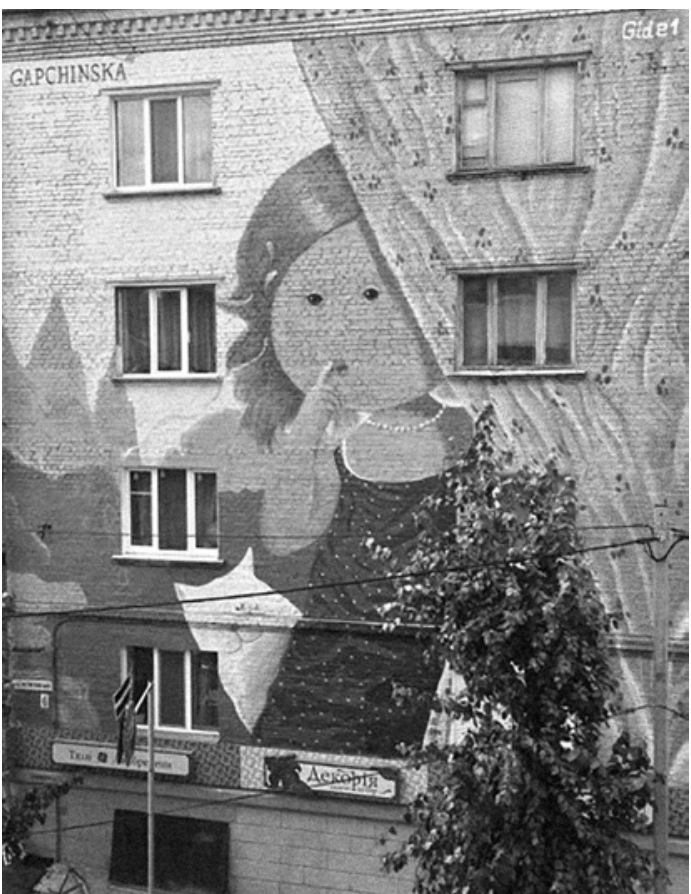

1. Mural by Vitaliy Gidevan based on the E. Gapchinska's motif of little angel girl and a cat. 6, Mstyslavska Street, Chernihiv. Photographed in 2017

2. Mural by Vitaliy Gidevan A Piece of Bread with Lard (project, 2008) based on E. Gapchinska's namesake work. Performed by M. Kyryliuk and A. Koshova at 102, Kalynova Street, Dnipro City. Photographed in 2019

reference points of certain subcultures, thus it may be entirely throughoutly supported.

Developing the storyline of such quite a "Ukrainian" (though in "modern" clothes) angel, E. Gapchinska gave her consent to implement her another artwork in mural art. This time, the refined image of the beauty of humble origin in traditional Ukrainian clothes (from the paining A Piece of Bread with Lard) was chosen. The prototype for the mural painting composition was the cute heroine of Gapchinska's

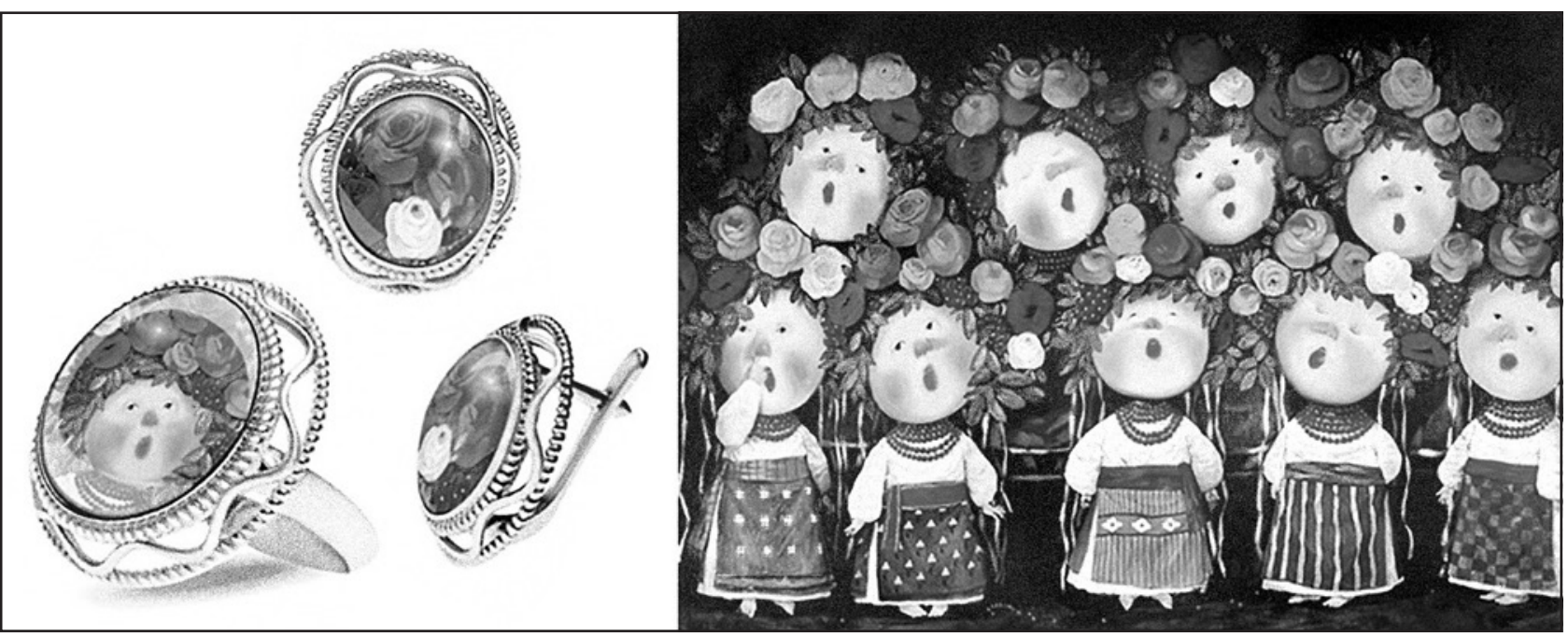

3. E. Gapchinska. Silver jewelry series, Viryovka Folk Choir motif. 2009 


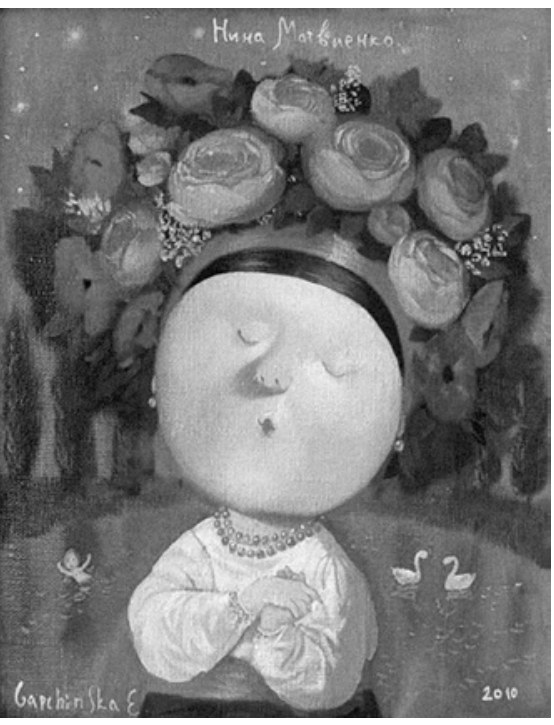

4. E. Gapchinska. Nina Matviyenko. 2010.
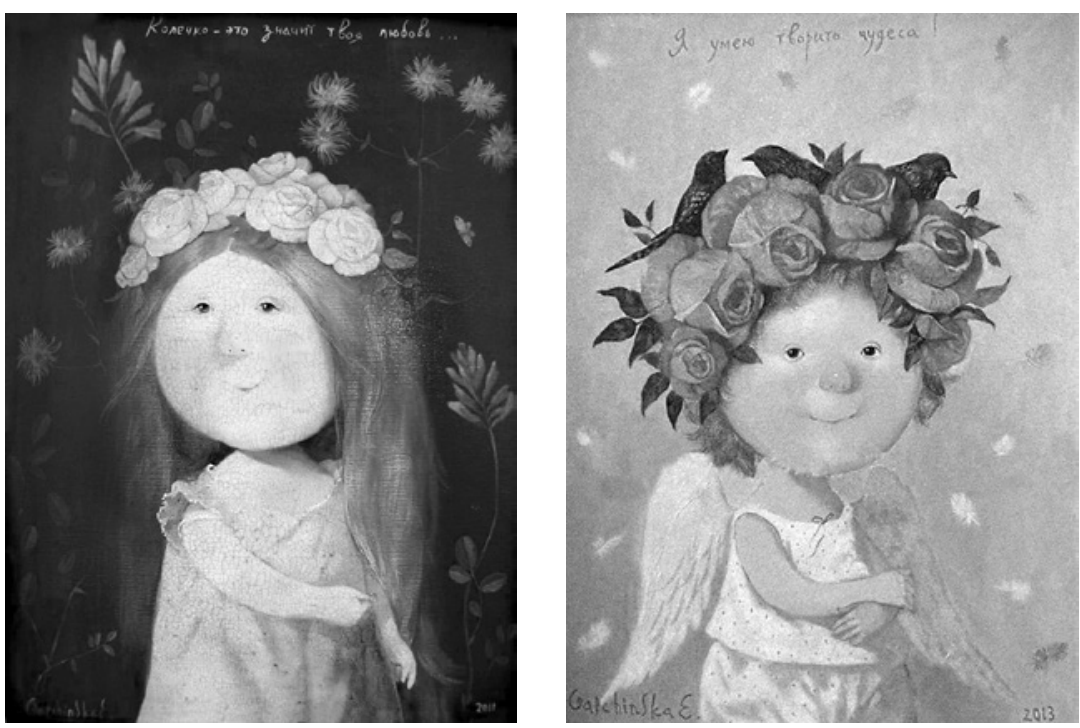

5. E. Gapchinska. A Ring Means Your Love... 2011. 6. E. Gapchinska. I Can Do Wonders... 2013 easel arts (2008) who was meant by the commissioners from the Municipality (Dnipro City Development Utilities Company), according to the publication [5], to "express" the issue of Ukrainian identity, since many mural artworks in Ukrainian cities had been earlier developed and implemented by foreign artists, i. e. Mexicans, Frenchmen, Spaniards, etc.

Meanwhile, some journalists erroneously believed that the Dnipro City Council decided to order a replica of the other cute little angel by E. Gapchinska, I Can Do Wonders... (2013), and reported that to the broad audience [4]. On the one part, such confusion speaks to the required analysis of artistic processes in contemporary mural art by professional art experts and, on the other part, perception of the E. Gapchinska's artistic style by the public and even confusion of certain images having certain similarity among them, since the artist, in the majority of her designs, does not deviate from the chosen creative method allowing her to make any image "dollish" and "glamorous" and implement the same in a non-primitive manner, as if illustrating a book for children.

Objectives of the study are to describe artistic features of mural painting images originated by E. Gapchinska, and to study her embarking on the topic of Ukrainian authenticity.

Presentation of the main research material. The pragmatic nature of glamour, which, in fact, "devours" nearly every art area and covers it with its "moiré", has recently flooded beyond show business, industrial design, graphical design and clothes design only. First of all, it can be felt in the field of environment design, both in interiors and exteriors of modern buildings, which is logical for development of a style, covering all kinds of art and architecture as it progresses.

In this regard, the recent experiments of E. Gapchinska are of great interest. In her artworks, she always tries to express her messages designated to involve a wider audience of her fans. Since simplicity and easiness of storylines, senses and contexts [11] are the key conditions of her artworks, the artist has been trying, for several recent years, to embark on the new field which would enable - through certain advertising - "cleaning of her artistic range", updating her tools, and finding deployment of her skills in various areas.

When analyzing the first experience of designing of a mural painting for a typical five-storey building at 6, Mstyslavska Street in Chernihiv City in 2017 by the co-authors, Kyiv-based painters Eugenia Gapchinska and Vitaliy Gidevan, it should be noted that the artists rather tried to find the line which would make street art of old Ukrainian cities resonate in a modern and updated manner. The heroes of the huge painting are a curious cute little angel girl and her loyal friend, a cat, painted in the manner and colors typical of E. Gapchinska [3] (fig. 1).

At the same time, it is worth understanding that certain "cloning" of images in glamour conditions (in the opinion of O. Lahoda, Candidate in Art Theory and Associate Professor of the Cherkasy State Technical University) is only welcomed, since it enables making them more sellable. Overhappiness and non-conflict superficiality of media heroes with touchy-feely expressing of senses are believed to be another element of Gapchinska's style and its specificity. Such features are close to the ideology of glam-capitalism, where the "frame", made perfect, becomes the key element of the new artistic language, its specific sign with new codes and cultural senses $[11$, p. 8$]$.

Due to the successful initial experience in mural art, the said artists (the author and the co-author) kept on their searches trying to understand what was the demand of contemporary communities in big Ukrainian cities. Thus, at the request of Dnipro City residents, the project of a mural painting inspired by one of the best works of E. Gapchinska, Viryovka Folk Choir (2009), was suggested.

In 2019, the mural painting was made in Dnipro City at 102, Kalynova Street. This time, the artwork was located far from the downtown, in one of dormitory districts of the city. The huge mural features a bit kitschy (somewhat simplified, study-like, standardized and mass-culture) Ukrainian girl "in full gear" (like Dzidzio at his concert), that is, in a beautiful, traditional, perfectly detailed and attractive costume with 


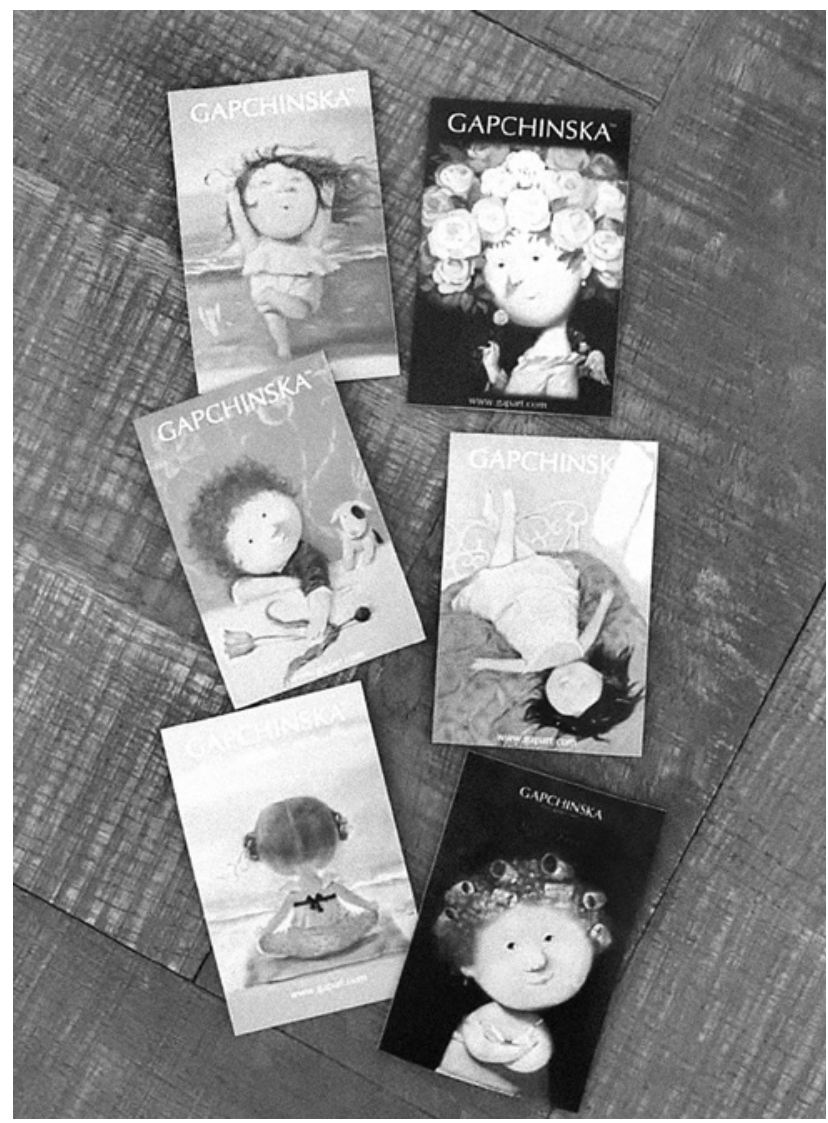

7. E. Gapchinska. Magnets. In the left upper corner, I'm Yours. 2010s

a multilayer chaplet made of fresh open roses with laurel-like leaves. However, the heroine is presented as a fairy-tale, even animated film character, although having certain monumentality and architectonic garments.

The artwork appeals to the constant features of the "deep Ukrainian authenticity" found in author's paintings, since it skillfully "hooks" devotees of the actual authentic values and eternal harmony. It is worth mentioning that E. Gapchinska devoted more than a dozen years to find such "perfect" model beauty. And she could not catch the required "stylistic nerve" for a quite long while.

Here, the key artist's painting designs in the said topic should be listed. They include, first of all, The Sky in My Palms (2006) (fig. 4), A Piece of Bread with Lard (2008) (the mural replica at 102 Kalynova Street, Dnipro City, 2019 (fig. 2)), Viryovka Folk Choir, (2009) (fig. 3), Nina Matviyenko (2010), A Ring Means Your Love... (2011) (fig. 5), I Can Do Wonders (2013) (fig. 6), I'm Yours ((?)2010s) (fig. 7).

Starting with The Sky in My Palms (2006), the painter has strived to find the flexible expression of the image enabling depiction of the "pristine beauty" covered with further artificial layering. Like pre-Raphaelites, beaux-art experts and Mykhailo Boichuk school, she was looking for her "proto-renaissance", however, not in Italy but rather in the Netherlandic, Flemish, Dutch and German medieval art, where somewhat awkward and even a bit grotesque and ridiculous, sarcastically transformed subconscious images were, in fact, designated to look deeper into the viewer's soul, eyes and heart, so that the viewer would not remain untouched.
Due to a year of internship at the Nuremberg Academy, E. Gapchinska during her studies, had a chance to grasp a deeper understanding of such Northern painters as Pieter Breugel de Oude and $\mathrm{H}$. Bosch, and better feel the painting manner of the European painting founder and proto-designer van Eyck, without whom Rembrandt would never succeed. That is why, the early images of authentic Ukrainians in paintings of E. Gapchinska had a mental hue of a post-Gothic oddish Northern person, where phantasmagoria aspects had to be abandoned without losing preciosity.

Thus, after The Sky in My Palms (2006), A Piece of Bread with Lard (2008) [2] emerged, with the latter having emancipated glamour features. Thereafter, this composition, which is now implemented in a mural painting, became perfectly finished in repeated characters cloned in the "iconostasis" titled Viryovka Folk Choir (2009). In her next artworks, E. Gapchinska attempted to "loosen" the form by adding more lyrics and sentimental sounding to it. As a result, the painting called Nina Matviyenko (2010) appeared, which is not so much focused on ethnographic details, and which may be called, without any exaggeration, another masterpiece in the artworks collection of E. Gapchinska, just like A Piece of Bread with Lard and Viryovka Folk Choir.

The painter makes Nina Matviyenko more expressive, using a deep blue background with a lapis lazuli hue, and with a lovely couple of white swans in the background, like in a folk picture. It is the swan song in the creative collection of Nina Matviyenko that was emphasized by E. Gapchinska in this artwork. Simplicity, naivety and sinking into the depth of own soul without any limits on the background of eternal stars guiding lives of talented people are laconically and extensively emphasized by the painter through, on the one side, a red ribbon on the head and the same holiday red belt, and, on the other side, plastically expressive and perfectly blue background with yellow stars. The concentrated images of this work may be only compared to the Gapchinska's 2010 painting Mona Lisa.

The artist tried to make her later artworks of the chosen topic-A Ring Means Your Love... (2011), I Can Do Wonders... (2013), I'm Yours ((?)2010s) — somewhat simpler if compared with the aforementioned ones. There, heroines feel excited due to the expectation of love or the "angel's mission”, rather than due to being Ukrainians. No previously dominating images with rose chaplets in hair in these new portrait-like paintings, only certain dreamy faces and immediateness of the moment. Perhaps, E. Gapchinska was seeking for some other states, and the compiling creative method applied in her previously mentioned works was not deployed in full here.

In this regard, going back to the murals implementing images of the best easel artworks of the author, it should be noted that the organizers had evidently studied the creative works of the painter before making a decision, and made the right choice of her "most Ukrainian" findings.

Since a mural painting based on a typical Gapchinska's artwork is already made on the residential building at the corner of the Yantarna and Kalynova Streets, the rest of the 
author's designs in the same direction may be expected to be implemented by other painters upon the artist's permission. Among the motifs of her popular easel artworks that may potentially become monumental and decorative artworks (as they are a priori decorative), it may be concluded that the portrait of an angel girl with flowers on her head and a sandwich with lard in her hand only starts a trend which has high public demand. It means that E. Gapchinska is already "cited", upon her permission, and there is high probability that this trend will develop with time. Therefore, it is also significant to understand the mechanisms of introducing such images into environments.

The mural painting in Dnipro City was implemented by painters Mila (Liudmyla) Kyryliuk and Andriana Koshova (the latter is from Pavlohrad, Dnipropetrovsk Region), invitees of the local Mural Fest. Before painting on the wall of the building, the project was coordinated with E. Gapchinska to obtain her permission to perform such picture on the façade according to the copyright requirements. Local residents are convinced that dark days would become brighter as public spaces are transformed into art objects. It is also worth mentioning that, before the implementation of the idea, the organizers had personally attended the meeting of cooperative associations in order to follow all applicable legal requirements and thereby gained the support of local residents and the approval of the prototype picture of the huge mural painting [2].

In general, taking into account the experience of E. Gapchinska in book graphics where illustration heroes became "alive" due to a special software application (first of all, the editions of Alice in Wonderland and Alice Through the Looking Glass by A-BA-BA-HA-LA-MA-HA Kyiv-based Publishers), and the experience of V. Gidevan in making of the "alive" animation of 12-metre mural (with the Augmented Reality technology for JuliviAr application, iOS or Android) on the façade of Kyiv Boarding High School No. 13 [1], the prospects of development of their cooperation in interactive murals that may get $7 \mathrm{D}$ features, like in contemporary Japanese digital arts, have a high potential of further progress. On this way, it would be crucial not to lose the identity which would not allow all originally Ukrainian things "dissolve" in the multicultural globalized space [7].

Conclusions. Such a bit "aggressive" component of the contemporary art multiplied by interest in interactive artworks (since the painter already has the experience of making images further animated) has all chances to persistently engage, with time, a wider consumer audience in the Ukrainian art market. As a matter of fact, the demand for authentic artworks by E. Gapchinska in various creative directions is gradually growing, which makes her popular and shows her the way to the role of a leading contemporary artist working on the crossroads of image-creation, decorative, applied, monumental and decorative arts, design (including graphics, web, industrial, environment and garments design) and street art, that may cover, in future, animation, holographic art, and stereo art. Meanwhile, glamour connected with a certain lifestyle within the framework of glam-capitalism is a significant worldview foundation of the painter's works.

\section{References}

1. V Kieve poyavilsya mural s dopolnennoy realnostyu: kak i gde uvidet risunok. URL: https://kiev.informator.ua/2019/03/26/v-kieve-poyavilsya-mural-s-dopolnennoj-realnostyu-kak-i-gde-uvidet-risunok/ (access date: 21.02.2020).

2. V Dnepre na Kalinovoy poyavilsya mural «Hlebushek s salom». URL: https://dp.informator.ua/2019/04/19/v-dnepre-na-kalinovojpoyavilsya-mural-hlebushek-s-salom/ (access date: 21.02.2019).

3. Myttsi u vidriadzhenni: kyivski khudozhnyky stvoryly charivnyi mural u Chernihovi. URL: https://nashkiev.ua/novosti/mittsi-ou-vidryadzhenni-kiivs-ki-houdozhniki-stvorili-charivniy-moural-ou-chernigo vi.html?in_parent=novosti (access date: 23.02.2020).

4. Na stene mnogoetazhki Dnepra budet krasovatsya rebenok-angel ot Gapchinskoy. URL: https://dv-gazeta.info/dneprnews/ na-stene-mnogoetazhki-dnepra-budet-krasovatsya-rebenok-angel-ot-gapchinskoy.html (access date: 03.03.2019).

5. Pozdnyakova O.L. Dizayn sovremennoy detskoy knigi kak iskusstvo // Vestnik Tambovskogo universiteta. Seriya: Gumanitarnyie nauki. 2013. Vyp. 2 (117). S. 207-211.

6. Shkolna O. Intehruvannia tvoriv obrazotvorchoho mystetstva v dyzain seredovyshcha na prykladi tvorchosti Yevhenii Hapchynskoi // Artprostir. 2018. \# 3. S. 97-100, 129.

7. Shchehelska Yu. P. Osoblyvosti zastosuvannia tekhnolohii dodanoi realnosti yak instrumenta peretvorennia drukovanoi produktsii na tryvymirnu v praktytsi promotsiinykh komunikatsii

\section{Мітература}

1. В Киеве появился мурал с дополненной реальностью: как и где увидеть рисунок. URL: https://kiev.informator.ua/2019/03/26/vkieve-poyavilsya-mural-s-dopolnennoj-realnostyu-kak-i-gde-uvidetrisunok/ (Аата обращения: 21.02.2020).

2. В Анепре на Калиновой появился мурах «Хиебушек с салом». URL: https://dp.informator.ua/2019/04/19/v-dnepre-na-kalinovojpoyavilsya-mural-hlebushek-s-salom/ (Аата обращения: 21.02.2019). 3. Митці у віАряАженні: київські художники створики чарівний мурам у Чернігові. URL: https://nashkiev.ua/novosti/mittsi-ouvidryadzhenni-kiivs-ki-houdozhniki-stvorili-charivniy-moural-ouchernigovi.html?in_parent=novosti (Аата звернення: 23.02.2020).

4. На стене многоэтажки Анепра будет красоваться ребенок-ангел от Гапчинской. URL: https://dv-gazeta.info/dneprnews/nastene-mnogoetazhki-dnepra-budet-krasovatsya-rebenok-angel-otgapchinskoy.html (Аата обращения: 03.03.2019).

5. Позднякова О.А. Аизайн современной детской книги как искусство // Вестник Тамбовского университета. Серия: Гуманитарные науки. 2013. Вып. 2 (117). С. 207-211.

6. Школьна О. Інтегрування творів образотворчого мистецтва в АИзайн середовища на приклаАі творчості Євгенії Гапчинської // Артпростір. 2018. № 3. С. 97-100, 129.

7. Щегельська Ю.П. Особливості застосування технологій доданої реальності як інструмента перетворення Арукованої продукції на тривимірну в практиці промоційних комунікацій // Поліграфія 
// Polihrafiia i vydavnycha sprava. 2019. Vyp. 1 (77). S. 101-110. doi: 10.32403/0554-4866-2019-1-77-101-110.

8. Baldini A. Philosophy to Street Art and the Law. [Leiden]: Brill, 2018. $100 \mathrm{p}$.

9. Gandl S., Kastelli K. The Glamur. Clio: Belgrad, 2007. 298 s.

10. GAPCHINSKA. URL: http://www.gapart.com/index.php?option $=$ com_gallery $2 \&$ Itemid $=8 \&$ id $=116 \&$ page $=1$ (access date: 02.03.2020 p.). і видавнича справа. 2019. Вип. 1 (77). С. 101-110. doi: 10.32403 /0554-4866-2019-1-77-101-110.

8. Baldini A. Philosophy to Street Art and the Law. [Leiden]: Brill, 2018. $100 \mathrm{p}$.

9. Gandl S., Kastelli K. The Glamur. Clio: Belgrad, 2007.298 s.

10. GAPCHINSKA. URL: http://www.gapart.com/index.php? option $=$ com_gallery2\&Itemid $=8 \&$ id $=116 \&$ page $=1$ (Аата звернен ня: 02.03.2020 р.).

11. Lagoda O. Glamoour as a conceptual product pf the present // GISAPF: Culturology, Sports and Arthistory.London, 2015 (December).

P.7-11. DOI: http://dx.doi.org/10.18007/gisap:csah.v0i7.1226

Аметова $\Lambda$.

ГАамурна україніка в мурахах Євгенії Гапчинської

Анотація. Розглянуто окремі мотиви в роботах вітчизняної художниці початку XXI століття Є. Гапчинської, втілені в сучасному мурал-арті. Окреслено коло основних тем і сюжетів, пов’язаних з українікою в ії творчості. Проаналізовано живописні роботи «Небо в моїх долоньках (2006), «Хлібчик із салом» (2008, репліка-мурал по вул. Калиновій, 102, Аніпро, 2019), «Хор імені Верьовки» $(2009$ (?)), «Ніна Матвієнко» (2010), «Кільце — це значить твоя мюбов ...» (2011), «Я вмію творити чудеса» (2013), «Я твоя» (2010-ті (?)), а також окремі мотиви янгомят, які надихнули В. Гідевана на створення проєктів стінопису в Чернігові (2017). 3'ясовано специфічні ознаки творчого методу художниці в зазначеній галузі.

Ключові слова: сучасний мурал-арт за мотивами живопису Євгенії Гапчинської, україніка, Чернігів, Аніпро.

Аметова $\Lambda$.

ГАамурная украиника в мурамах Евгении Гапчинской

Аннотация. Рассмотрены отАельные мотивы в работах отечественной художницы начала XXI века Е. Гапчинской, которые нашли воплощение в современном мурал-арте. Очерчен круг основных тем и сюжетов, связанных с украиникой в её творчестве. Проанализированы живописные работы «Небо в моих мадошках» (2006), «Хиебушек с салом» (2008, реплика-мурал по ум. Калиновой, 102, Анепр, 2019), «Хор имени Верёвки» (2009 (?)), «Нина Матвиенко» (2010), «Кольцо — это значит твоя нюбовь ... (2011), «Я умею творить чудеса» (2013), «Я твоя» (2010-е (?)), а также отдельные мотивы ангелочков, вдохновившие В. Гидевана на создание проектов стенописи в Чернигове (2017). Выяснены специфические признаки творческого метода художницы в указанной области.

Ключевые слова: современный мурал-арт по мотивам живописи Евгении Гапчинской, украиника, Чернигов, Анепр. 